\title{
CHRONOLOGY OF KEY EVENTS OF RIGA TECHNICAL UNIVERSITY
}

\author{
IN STUDY YEAR 2018/2019
}

\section{8}

\section{September 1}

Faculty of Power and Electrical Engineering (FPEE) celebrated its 60 th anniversary. Excursions in the former building of the faculty at 1 Kronvalda bulvāris and at the present building at $12 \mathrm{k}-1$ Azenes iela in Kìpsala, as well as a social event at 1 Kalku iela took place.

\section{September 12-14}

The 4th year's student team of the Bachelor's Professional Study Program «Trantsportbūve» («Transport Building») of Faculty of Civil Engineering (FCE) - Romāns Kornišovs, Kristaps Maneks and Juris Latišs got the second place in the 3rd International Transport Building Student Olympiad in Minsk, Belarus.

\section{September 14-21}

School year 2017/2018 graduate of RTU Engineering High School (EHS) Roberts Pavlovskis got the Gold Medal at the International Economics Olympiad in Moscow.

\section{September 17-21}

RTU was organizing the Most Powerful Conference on Power Electronics «EPE 2018» of European Power Electronics and Drives Association (EPE).

\section{September 18}

RTU joined the Magna Charta Observatory (Magna Charter Universitatum). At a solemn ceremony held in Spain, at the University of Salamanca, the accession document was signed by RTU Vice-Rector for Strategic Development Artūrs Zeps. The Spanish King and Queen, Rector of the University of Bologna, President of the Magna Charta Observatory and representatives of other universities took part at the ceremony.

\section{September 27}

The best-equipped and most modern metrology laboratory in the Baltics «Mitutoyo» was opened at RTU Laboratory Building at 1 Paula Valdena iela, Room 106 within the Faculty of Mechanical Engineering, Transport and Aeronautics (FMETA). 


\section{September 28}

With the decision of the Senate of RTU (Minutes No. 622) the title of RTU Honorary Doctor was granted to Professor of Chair of Mechanics and Robotics of University of Duisburg-Essen Andrés George Kecskeméthy Darányi.

\section{September 29}

RTU students Daniils Bobrovs (FMETA), Gustavs Vìksne (Faculty of Computer Science and Information Technology; FCSIT) and Tomass Jegorovs (FCSIT) as well as graduate (2018) of the Faculty of Engineering Economics and Management (FEEM) Girts Feldbergs took part in a $100 \times 100$ meter freestyle relay swim dedicated to the centenary of Latvia. That was an attempt to beat the Guinness World Record. Latvian swimmers reached a world record in a swimming relay $(1: 30: 28)$ in a 50-meter swimming pool, Guinness's record (1:29:03) was reached in Britain in a 25-meter pool.

\section{October 3}

RTU signed cooperation agreement with Latvian Academy of Sport Education on cooperation in studies, science and innovation and student exchange.

\section{October 5}

RTU and five other Latvian universities signed the Memorandum of Cooperation on Efforts to strengthen sustainability in Latvia. The Memorandum was signed at the seminar «Augstskolu loma un atbildība Latvijas ilgtspējas veicināšanā» («Role and Responsibility of University Institutions in Promoting Sustainability in Latvia») of «GreenMetric» which was held at RTU.

\section{October 5-7}

Students of Bachelor's Professional Study Program «Material Technology and Design» of Institute of Design Technologies (IDT) of The Faculty of Materials Science and Applied Chemistry (FMSAC) Ieva Kreile and Santa Pikuma acquired Annual Award 2018 from the Latvian Designers' Society in the category of universities in sub-category «Product Design».

\section{October 10}

The second RTU History Day and the 59th International Scientific Conference in the Section of History of Engineering Sciences and Institutions of Higher Education were held. The second volume in Latvian and English of the scientific journal of RTU Research Centre for Engineering History (RCEH) and popular-scientific book «Riga Technical University. Half a Century on Kìpsala» were opened. 


\section{October 12}

At the 59th plenary session of the International Scientific Conference, the title «RTU Scientist of the Year 2018» was awarded to Senior Researcher of FMSAC Jānis Ločs; the title «RTU Young Female Scientist of the Year 2018» was awarded to Researcher of FMSAC Arita Dubnika; the title «RTU Young Scientist of the Year 2018» was awarded to Senior Researcher of Faculty of Electronics and Telecommunications (FET) Andis Supe; RTU Annual Award for Valorisation received Professor of FPEE Dagnija Blumberga; for the first time the prize in valorisation was presented to the student, it received Researcher of FMSAC Uldis Peipinš; the title «RTU Honorary Alumnus 2017» was awarded to Chairman of the Board of «HansaMatrix» Ilmārs Osmanis; for the first time the lecturers were congratulated: the «RTU Annual Academic Excellence Award 2018» was awarded to Associate Professor of FCSIT Alla Anohina-Naumeca; Honorary title «RTU New Lecturer of the Year 2018» was awarded to lecturer of FEEM Leonards Budniks; development grants were awarded to Dean of FEEM Professor Elina Gaile-Sarkane; Professor of FMSAC Svetlana Čornaja and Professor of FCSIT Inta Volodko.

\section{October 16-18}

In Frankfurt, during the «InterGeo» Forum, work «The Use of Combined Methods for Precise Topographic Data Acquisition» of undergraduate of Professional Study Program «Geomatics» of FCE Rūdolfs Mellēns was acknowledged as the Winning paper of CLGE Student Contest in category Geodesy, Topography.

\section{October 16-19}

For the third year in a row, FEEM and the Riga Business School (RBS) of RTU saved the Four Leagues of Palms of Excellence at «Eduniversal» rating.

\section{October 17}

Pupils of the 10th grade of RTU EHS took part in the world's largest lesson, which took place in Vecumnieki village and was being developed in cooperation with the company «Latvian State Forests».

\section{October 18}

President of Latvia Raimonds Vējonis, Minister of Education and Science Kārlis Šadurskis and Head of the National Centre for Education of the Republic of Latvia Guntars Catlaks at the solemn ceremony at Riga Castle welcomed secondary school pupils who had successfully participated in international training Olympiads. Among them were pupils of RTU EHS: graduates of EHS - Roberts Pavlovskis (Gold Medal in the 1st International 
Economic Olympiad); Tomass Ernests Auziňš (Bronze Award at the 29th International Biology Olympiad); pupil Artems Ubaidullaevs (recognition at the 59th International Mathematical Olympiad), pupil Jana Bolmante (participation in the International German Olympiad).

Gratitude for contributing to the preparation of Latvian pupils for the International GENUS Olympiad was given to the Researcher of the Institute of Technology of Organic Chemistry (ITOC) of FMSAC Krista Suta.

\section{October 29}

With the decision of Senate of RTU (Minutes No. 623) Institute of Mechanics (IM) and Institute of Mechanical Engineering (IME) of FMETA was reorganized and their obligations and rights were taken over by the newly established structural unit - Institute of Mechanics and Mechanical Engineering.

\section{October 31}

RTU, Riga Stradiñš University (RSU) and BA School of Business and Finance (BASBF) signed an agreement on cooperation in cyber security competences.

RTU acquired the 57th place in rating «QS Emerging Europe and Central Asia (ECCA) 2019».

\section{November 5-9}

RTU delegation under the leadership of Rector Academician Leonìds Ribickis attended five institutions of university educations - Kyungpook National University (Daegu, Korea), Daegu Gyeongbuk Institute of Science and Technology, National Taiwan University of Science and Technology (Taipei, Taiwan), WuFeng University (Chiayi, Taiwan), Hang Seng University of Hong Kong (Hong Kong, China) to sign a cooperation agreements, discuss the success of the cooperation and mark new opportunities.

\section{November 7}

RTU ranked 801st+ place in the new rating «Times Higher Education», which evaluates university performance in natural science.

\section{November 8}

RTU Rector Academician Leonìds Ribickis at Hong Kong City University in China received the «World Cultural Council» award for contributing education. 


\section{November 12-15}

The Electronic Week organized by the Student Self-government of faculty took place at the FET. During event, guest lectures and workshops of well-known companies of electronics and telecommunications were held. The work « Balerina» by the team of RTU EHS - Aleksejs Jekimovs, Alise Anna Stipniece and Evelina Valtere received the Innovation Award «Elektronikas dienas 2018» the exhibition of works of Electronics Hobby Club.

\section{November 16}

Senior Researcher of the Institute of Applied Chemistry of FMSAC Kristaps Mālinšr received the highest award of the Jelgava Region Honorary Diploma.

\section{November 17}

The Director of Institute of Transport Infrastructure Engineering of FCE, the Head of Department of Roads and Bridges Professor Dr. sc. ing. Ainārs Paeglitis received the Cross of Recognition, III Class.

Head of RTU Defence and Military Technology Research Centre, Chief of Intelligence Division of the National Guard Student Battalion of the Latvian National Guard, Head of the National Guard Science, Research and Innovation Implementation Center Captain Juris Kiploks received the Order of Viesturs, V Class.

\section{November 21}

The Cabinet of Ministers (CM) of the Republic of Latvia decided to reorganized Mechanics and Technology College of Olaine by joining to RTU from 1 July 2019.

\section{November 29}

Latvian Academy of Sciences (LAS) at Autumn General Meeting elected FMSAC Professor Valdis Kokars as Academician and choose Senior Researcher of FMSAC Jānis Ločs and Dean of FET Professor Jurǵis Porinǧs as LAS Corresponding Members.

\section{In November}

With the successful co-operation and support in contributing to the defence and security of Latvia, Minister of Defence Raimonds Bergmanis presented the Honorary Certificate of Ministry of Defence of Republic of Latvia to RTU Rector Academician Leonìds Ribickis.

Andris Šutka, a new scientist of FMSAC, received the prestigious TOYP (Ten Outstanding Young Persons) award for outstanding achievements in science. 
RTU was included among the top universities in engineering and technology, ranked 501-600 place at «Times Higher Education (THE) World University Rankings 2019 by subject: Engineering and Technology». RTU was also included in the ranking of IT science industry organized by THE.

RTU received an outstanding rating of five stars in the international ranking of universities «QS Stars». The five-star system assessed the university's performance in eight categories; RTU acquired evaluation of top five stars in six categories.

\section{December 6}

RTU EHS received the LAS Award in Education and Science - Honorary title of Cicerone.

\section{December 10}

Professor Aivars Vilnis Krastiņ̌s, Director of the Institute of International Business and Customs (IIBC) of FEEM was awarded with the State Revenue Service (SRS) Badge of the Honour, Badge of Honour of the First Class for personal contribution to the development of the SRS by establishing and strengthening the customs and tax education system in Latvia.

IIBC of FEEM received Certificate of Recognition for the acknowledgment of long-term cooperation, promoting the achievement of the SRS goals. SRS also expressed gratitude to Associate Professor of Chair of Customs and Taxes of IIBC Maris Jurušs for participation in elaboration of excise duty gap methodology and conducting research on illegal movement of excise goods, involving students who promote SRS goals.

\section{December 12}

RTU EHS received the Friendly Calling Fund Award. It has been recognized as the best secondary school of the city in Latvia in the group of big cities in the ranking of the Friendly Calling Fund for 2017/2018 school year; and receives prizes for best results in mathematics, Latvian and literature, natural sciences. RTU EHS also receives an award in the nomination «Izaugsme» («Growth»). In English nomination, the school has won a high second place in the group of city secondary schools. At the general meeting of the RTU Student Parliament (RTU SP) the student of FCSIT Katrina Rudoviča was elected as a new president of RTU SP.

\section{December 13}

Annual Awards of «Latvenergo» and LAS were awarded to three scientists: Associate Professor of the Institute of Industrial Electronics 
and Electrical Engineering (IIEE) Pēteris Apse-Apsitis received the LAS Award named by Alfrēds Vittols for outstanding contribution to energetic; Senior Researcher of IIEE of FEEM Jānis Zakis and Senior Researcher of Scientific Laboratory of Functional Materials Technologies (SLFMT) of FMSAC Andris Šutka acquired the award of «Latvenergo» and LAS for significant contribution to energetics; the young scientists Liga Grase and Polina Ivanova, who had developed and defended doctoral theses at RTU (2017, 2018) received the 2018 Award for Success in the Energetics; 11 students of RTU (10 from FPEE; one from FMETA) received awards from LAS for successful defending of diplomas.

\section{December 17}

By decision of the Senate of RTU (Minutes No. 625), the Centre of Industrial Design and Ergonomics of the Institute of Mechanics of FMETA was liquidated by establishing the Chair of Industrial Design.

\section{December 20}

Award of Civil Engineer Guntis Bole was handed to graduate of Faculty of Architecture (FA) Agnija Pastare and to 4th year student of study programme «Heat, Gas and Water Technology» of FCE Raimonds Bogdanovčs at the FA. At the same event the Latvian Regional Architecture Premium of Professor Ivars Strautmanis was awarded to graduate of FA (2018) Luīze Marta Aizpurva.

\section{In December}

LAS announces 12 major achievements in Latvian science in 2018, including research conducted by RTU scientists:

- researches on the development of triboelectric (nano)generators carried out by scientists of the SLFMT of FMSAC and the Institute of Technical Physics (Andris Šutka, Kaspars Mālnieks, Artis Linarts, Linards Lapčinskis, Juris Blūms, Ilgvars Gorn,evs, Vilnis Jurkūnns, Astrīda Bērzinga, Māris Knite);

- Book by Professor of FA Jānis Krastinš «Jūgendstila arhitektūra Latvijā» («Art Nouveau Architecture in Latvia») (2018);

- uncovering of unusual DNA forms with unusual packing and genome service functions in human cells; Hermanis Sorokins and Jēkabs Krigerts, scientists of the Institute of Biomedical Engineering and Nanotechnologies (IBEN) of the FMETA had also participated in the research;

- $\quad$ portable device for early contactless diagnostics for skin cancer; the research has been carried out by the scientists Dmitrijs Bliznuks, Katrina Boločko, Pāvels Osipovs, Mihails Kovalıvs, Jurijs Jonass, 
Gundars Miezitis and Andrejs Kalniņš of FCSIT in cooperation with the researchers of the University of Latvia (UL);

- the book «Nonregular nanosystems: theory and applications» (2018); one of the authors of the book is researcher of the Institute of Aeronautics of FMETA Tamāra Lobanova-Šunina.

RTU was ranked in 128th place in Green Policy and Sustainability Rating «GreenMetric» and is the greenest university in Latvia.

\section{9}

\section{January 4}

The Exhibition \#ZinātneLatvijai created by the Ministry of Education and Science (MES) was opened at the fashion and entertainment center «Riga Plaza» at 71 Mūkusalas iela. The exhibition was also attended by Senior Researcher of Institute of Telecommunications (IT) of FET Sandis Spolitis, Associate Professor and the Head of the Chair of Environmental Protection and Heat Systems of FPEE Jūlija Gušča, graduate of FMSAC Kristaps Jaudzems and graduate of FMETA Dainis Jakovels.

\section{January 16}

Robotics Hobby Group of RTU EHS participated in the largest Festival of Robotics in the world «Robotex» in Tallinn in 2018 gaining the 3rd place in girls competition and outstanding success in other categories of competitions, reaching the top of world ratings.

\section{January 17}

The opened competition organized by the RTU Procurement Unit for the construction of the FCSIT building and Public Auditorium Centre at RTU Campus in Kīpsala was recognized as «Annual Procurement» in 2018.

\section{January 22}

Ambassador Extraordinary and Plenipotentiary of the Republic of Chile Hernan Bascuñán-Jiménez, third Secretary of the Embassy of the Republic of Chile Michel Lavin and the Honorary consul of the Republic of Chile to Latvia Marc Fedder attended the RTU.

\section{January 23}

The FEEM opened the «Bloomberg» laboratory, giving access to a wide range real-time databases, researches and analysis tools for students and researchers. 


\section{January 28}

Graduates and teachers of RTU EHS were awarded with the Honorary Diplomas and Medals of the Friendly Call Foundation. In the nomination «Absolvents» for outstanding achievements, Bronze Medal at the International Biology Olympiad in 2018 was awarded to the graduate Ernests Tomass Auzinšs; Roberts Pavlovskis was awarded for the gained Gold Medal at the 2018 Economic Olympiad; graduate Vladislavs Aščeulovs was awarded for the gained Bronze Medal at the 2017 International Chemistry Olympiad. Three teachers were awarded in the nomination «Skolotājs»: Biology teacher Dace Bērtule, Economic teacher Uldis Kamols, Chemistry teacher Laura Fjodorova.

\section{January 29}

The symbol of FMETA - the gear - was moved from 36 Viskalu iela to Kïpsala and placed in front of the building at 6B Āzenes iela.

\section{January 31}

RTU celebrated the Chinese New Year. The event was attended by Rector Academician Leonìds Ribickis, Ambassador of the People's Republic of China to China Huang Yong and RTU Students from China.

Assistant Professor of Chair of Telecommunications Networks of FET Viktors Zagorskis received the Annual Award of Latvian Open Technology Association for active position, confidence and participation in acquiring open technologies and open source code solutions, in preparing educational materials and educating the public, including doctoral students and professors.

\section{In January}

RTU was ranked 196th among the world's most prestigious rating agencies «Times Higher Education» (THE), in the rating of the new economy states' universities «THE Emerging Economies University Rankigs 2019», earning the highest rating among Latvian universities.

RTU Rector Academician Leonīds Ribickis visited the University of Las Palmas de Gran Canaria in Spain and meet with its Rector Rafael Robaina Romero and Vice-Rector for Internationalization and Cooperation Richard Clouet, as well as Carlos M. Travieso-González a representative of the Faculty of Telecommunications and Electronics.

\section{February 3}

RTU florbolists became champions of the XXIX Universiade of Latvia. 


\section{February 4}

RTU signed a new contract with the MES on the training of specialists and ensuring the development of scientific activity on the resources of the state budget.

\section{February 8}

Deputy Chairman of the Council of Ogre Municipality Egils Helmanis and RTU Rector Academician Leonīds Ribickis signed a cooperation agreement, continuing the previously successful cooperation.

\section{February 13}

In the Shadow Day, RTU scientists and employees were followed by 180 «shadows». Five «shadows» of RTU scientists also followed by the largest particle physics laboratory - the European Organization for Nuclear Research (CERN) in Switzerland. US Ambassador to Latvia Nancy Bikoff Pettit visited the RTU Design Factory on the Shadow Day.

\section{February 15}

The first RTU and RSU joint graduation of bachelor's professional study program «Medical Engineering and Physics» happened. 12 graduates received a joint diploma of both universities.

\section{February 16}

2nd year student sprinter of FMETA Kristaps Sietiňš became a Latvian champion in $60 \mathrm{~m}$ sprint hurdle race indoors (7.94) at Kuldiga Latvian Championship in Indoor Athletics and qualified for European Championship.

\section{February 28}

The open-type prototyping workshop «theLAB Césis» of the regional affiliate of the RTU Design Factory «theLAB» network was officially opened at RTU Césis Affiliate.

\section{In February}

The 3rd year students of the study program «Material Technology and Design» of the IDT of the FMSAC were evaluated in a competition organized by «Modernists» dedicated to the centenary of «Bauhaus». Paula Kristiāna Kalnina was recognized as the winner of the competition, the second best was Alise Sietniece and the third - Jānis Martulevs.

\section{March 1}

RTU Rector Academician Leonīds Ribickis and 38 scientists from 13 European Union (EU) Member States signed a joint communiqué expressing commitment to make the EU as the world's strongest 
community and leader in education, research, innovation, quality and ethical standards by 2050 .

\section{March 5}

Embassy of India in Sweden and Latvia organized Student Day at RTU.

\section{March 18}

RTU Rector Academician Leonīds Ribickis during his visit to Italy signed an agreement with Rector University of Trieste Professor Maurizio Fermeglia on co-operation in bioengineering, biomedical engineering, biochemistry, medical physics and biotechnology.

\section{March 21}

The exhibition «Kīmisko elementu periodiskā tabula - no Mendelejeva līdz šodienai (1869-2019)» («The Periodic Table of Chemical Elements - from Mendeleev to Present (1869-2019)») of Mendeleev Tables was opened at FMSAC. The exhibition was a donation to the faculty by the long-standing chemistry teacher of Iecava Secondary School Mihails Gorskis.

\section{March 23}

2nd year student Reinis Krauklis of FCE won the final stage of the Badminton Tournament «Victor Latvia GP 2019», which took place at the Salaspils Sports Complex.

\section{March 25}

By decision of the Senate of RTU (Minutes No. 628), by reorganising the Department of Maintenance such structures were established: Infrastructure Department and Student Hostel Department; by reorganizing the Administrative Department, Administrative Service Office of the Director of administration was established.

\section{March 26}

The conference «Pārmaingas ilgtspējīgai augstākajai izglītībai» («Changes to Sustainable University Education») dedicated to the future of university education took place at the Scientific Library of RTU, with the participation of the Minister of Education and Science of the Republic of Latvia Ilga Šuplinska and members of the Education, Culture and Science and Sustainable Development Committee of the Saeima.

\section{March 27}

The Prime Minister of the Republic of Latvia Krišjānis Kariņš presented awards to the Director of the IDT of FMSAC Dana Belakova and the oldest computer systems and computer network Administrator at the Computing Center of FCSIT Dagnis Zemturis for preparing young people for a successful competition «Euroskills 2018». 
Pupil of RTU EHS Artems Ubaidullaevs and graduate Ernests Tomass Auzinš as well as their teachers Inguna Granta and Dace Bērtule were awarded with the Diplomas of Cabinet of Ministers on outstanding achievements in international training Olympiads.

\section{March 28}

RTU opened a scientific photo exhibition of the CERN at the Liepāja Affiliate, giving an opportunity to learn how the Large Hadron Collider works.

\section{March 31}

RTU dance group «Vektors» with concerts at VEF Culture Palace celebrated its 60th anniversary.

\section{In March}

Researcher of IT of FET Jānis Braunfelds received the Annual Award in Science and Research of Defence Industry on research «Bregg Grating Optical Sensors».

Director of Scientific Research Laboratory of Biotextile Materials of FMETA Inga L Lašenko won the second place and gained the money award at the competition «Latvijas-Amerikas Inovāciju balva 2019» («LatvianAmerican Innovation Award 2019»), PhD student of Institute of Applied Computer Systems of FCSIT Ëvalds Urtāns received the Honorary certificate.

\section{April 3}

The third edition of the book «Biznesa ekonomika» («Business Economy») by RTU Honorary Doctor Kjell Gunnar Hoff with the participation of Norway Ambassador to the Republic of Latvia Kristian Ødegaard was launched at RTU RCEH.

RTU ranked the 201st-300th place in the rating «The Times Higher Education Impact Rankings 2019».

\section{April 4}

At the LAS 2019 Spring General Meeting, the new scientist of the ITOC of FMSAC Armands Sebris on the master's thesis « Synthesis and Photophysical Properties of Amorphous Purine-Azole Conjugates» received LAS Emilija Gudriniece Prize in chemistry and technology of chemistry.

\section{April 8}

On 8 April 2019, President of the Republic of Latvia Raimonds Vējonis and the Chapter of Orders decided to award the Cross of Recognition 
for special merits in favour of the State of Latvia: Dean of the FMETA Professor Ériks Geriňš and Professor of Chair of Theoretical Mechanics and Strength of Materials, Correspondent Member of LAS Jānis Vība; Director of Institute of Inorganic Chemistry of FMSAC, Senior Researcher, Academician of LAS Jānis Grabis. The solemn award ceremony took place on 3 May in Riga Castle.

\section{April 10}

Traditional fashion show of ITD of FMSAC «Kīpsalas pavasaris 2019» («Spring of Kïpsala 2019») celebrated its 15th anniversary.

\section{April 16}

JSC «Augstsprieguma tīkls» concluded a cooperation agreement with RTU and in the lobby of FPEE revealed the exhibition «Moving Energy». On 10 May, the exhibition travelled to Liepāja Affiliate of RTU, where it was opened until 25 May.

\section{April 18}

FEEM opened the Customs Control Laboratory.

\section{April 24}

RTU, UL, MES, New York State University of Buffalo established a new study program «Computer Science and Organizational Technologies». For the first time, the program is financially supported by the MES, the Ministry of Economics, banks and the IT industry.

\section{April 26}

The Senior Researcher of the Institute of Construction Technology of FCE Videvuds Ārijs Lapsa, had been awarded the «Medal for Inventors» of the World Intellectual Property.

\section{April 29}

The head of RTU dance group «Vektors» Uldis Šteins received the first Latvian highest award in professional dance art. Dagmāra Bārbale, the current leader of the dance group, was awarded the «Choreographer of Stage Folk Dance».

By decision of RTU Senate (Minutes No. 629), by the reorganization of the Administrative Department (Minutes No. 628), Administrative Service Office of the Director of administration (ASOD) was established and its regulations approved. Subordinate to ASOD: Personnel and Working Environment Department; Information Technology Department; Maintenance Department; Student Hostel Department; Property and Investment Department; Scientific library; Culture Centre; Sports Centre. 
By decision of RTU Senate (Minutes No. 629) RTU Department of Business Development and Investment was liquidated, its structures were transferred: Alumni Unit to Department of Public Affairs; Business Development Unit to Project Management and Development Department; Investment Attraction and Property Lease Unit, changing its name to «Property and Investment Department», to the ASOD.

\section{In April}

The World Customs Organization (WCO) endorsed the renewed international standards for the profession of customs officers developed at the FEEM IIBC. The WCO expressed its gratitude to RTU for the renewal of the standards.

\section{April 27-May 1}

At the Baltic Olympiad in Informatics in Tartu, Estonia, the 11th grade pupil Kārlis Šusters of RTU EHS won the Bronze Medal.

\section{May 9-11}

At the «XII International Aventics Pneumobile Competition», FMETA teams won several award-winning places:

RTU team «Riga Fresh» (captain Artūrs Rugājs, participants Kristians Radinnš, Ojärs Seglērs, Elza Sokolovska, technician - FMETA lecturer Māris Gailis, trainer - Head of laboratory of Chair of Automotive Engineering (CAE) of Institute of Transport (IT) Jānis Rudzittis) with the four wheel pneumobile won the 1st place in distance competition with more than 30 teams, setting a new Latvian record $-10.6 \mathrm{~km}$. The team also won the $2 \mathrm{nd}$ place in the acceleration discipline (dragreiss) in a distance of $220 \mathrm{~km}$ in 56 seconds achieving speed $-50.3 \mathrm{~km} / \mathrm{h}$ and received the main prize of «National Instruments» company for the best command and control system.

RTU team «Riga Airmobile» (captain Dāvis Serds, participants Renārs Rutulis and Feride Ločmele, trainer - IT CAE Assistant Valdis Priede) with the three wheel pneumobile won the 2nd place in agility driving discipline and 3rd place in acceleration discipline.

\section{May 16-17}

For the first time in the Baltics RTU was hosting an international annual conference «ICAReAlumni 2019» organized by RTU Alumni Association in cooperation with Porto Business School and Centre for Social Studies from Portugal.

\section{May 18}

For the first time in the History Museum of Customs and Taxes, FEEM was hosting a Museum Night event, providing a glimpse into the 
everyday life of custom officers. The event was created in cooperation with the Customs Board of the State Revenue Service and the Bauska Museum.

\section{May 22}

RTU and LMT launched a new business and science cooperation initiative - «Industrial Doctor» to promote creation of innovations for the Latvian economy.

The Jury of the association «Building Design and Construction Council» in cooperation with the Riga City Council Department of Property in the contest «Woman in Architecture, Construction, Design 2018» awarded Docent of Chair of History and Theory of Architecture of FA Agrita Tipāne, for her contribution to the field of architecture; administrator of Study Office of Chair of Architectural Design Inguna Dumbere for achievements in architecture promotion.

\section{May 25}

RTU women's choir «Delta» celebrated its 60th Anniversary with a concert in RTU Great Hall, at 1 Kalku iela.

\section{May 27-31}

For the first time the 8th International Staff Training week of RTU took place at the RTU RCEH Exhibition Hall at 1 Kronvalda bulvāris.

\section{May 29}

FPEE the Institute of Energy Systems and Environment (IESE) received the 1st prize in the category «Urban development. Developing cities resilient to climate change» in the competition of the Ministry of Finance «RegioStars Latvija 2019».

\section{May 31}

In anticipation of 60th anniversary, the RTU Men's Choir «Gaudeamus» was performing in the former Riga Steam Water Pumping Station at 196 Maskavas iela, where no concert has been performed so far.

\section{In May}

RTU scientist - Inga L Lašenko, Head of the Biotextilematerials Research Laboratory and her team of researchers (RTU FMETA Professor Olga Kononova, UL Scientist Dace Grauda, RSU Scientist Jūlija Rombovska) - won the International Women's Design Innovation Award for Nano-thread invention.

\section{June 8}

RTU vocal group « Jauna nianse » celebrated its 20th anniversary with a concert in the RTU Small Hall, at 1 Kalku iela. 
June 17-22

Kārlis Rimaševskis, a pupil of RTU EHS, received a Bronze Medal and Uǵis Vevers received a recognition at the International Young Scientists' Competition «Genius Olympiad» in Oswego, New York.

\section{June 17}

By decision of the RTU Senate (Minutes No. 631), the title of RTU Honorary Doctor was granted to Professor Hidenori Mimura, Director of the Research Institute of Electronics of Shizuoka University (Japan); RTU BALTECH Study Centre was included in the FEEM

\section{June 20}

The third RTU Grand Graduation took place in «Arena Riga».

\section{June 21}

FMSAC opened a new laboratory where faculty researchers will work with «Microactivity effi» reactor for the production of liquid fuel components from carbon dioxide $\left(\mathrm{CO}_{2}\right)$ and carbon monoxide (CO).

\section{In June}

RTU scientists Jana Vecstaudža (FMSAC) and Laura Dembovska (FCE) received a scholarship for «Women in Science» from «L'Oréal Baltic». RTU Student brass band «SPO» at the International Brass Band Festival with 13 bands competition in Italy in the nomination of «Brass Bands and Dance Groups» together with the dance group under the guidance of Gita $\bar{U} d r e$ won the 1 st place and the Gold Cup.

RTU was ranked in 701-750 place in the international rankings «QS World University Rankings 2020».

RTU was highly ranked in the international ranking of universities «U-Multirank», being the only one in Latvia received the supreme number of highest or A-level ratings in 11 evaluation criteria.

\section{July 2}

RTU Rector Academician Leonīds Ribickis received a Certificate of Commendation from the President of Latvia Raimonds Vējonis. It was awarded for personal contribution to the formation of knowledge society and the development of exact sciences in Latvia.

\section{July 5}

RTU was included in the «200+» category in the International European Training Ranking THE (Times Higher Education), which includes all universities ranked in 200-258th place. RTU is included in this rating for the first time. 
July 23

RTU Rector Academician Leonìds Ribickis meet members of the summer camp - school for talented Latvian students «Alfa» and, inspiring for future challenges in engineering, presented a book about RTU Honorary Member Mikhail Dolivo-Dobrovolsky.

\section{In July}

For the eighth year in a row from the employers RTU has been admitted as the most highly recommended university in Latvia.

\section{In August}

RTU EHS ranked the second place in the Star Rating of Atis Kronvalds Foundation (Best International Olympics Results).

\section{August 3-11}

The International Exhibition Centre BT1, in Ķīpsala, hosted the largest international chess festival in Northern Europe, «RTU Open 2019», the winner of whom was Latvian chess player Igors Kovalenko.

\section{August 4-11}

Kärlis Šusters, a pupilof RTU EHS, won a bronze medal at the 31st International Olympiad in Informatics in Baku (Azerbaijan) along the 325 participants.

\section{August 9}

Regina Ines Aujesky (b. Nauck) the great-great-granddaughter of Professor Ernst Nauck, the first director of Riga Polytechnicum, visited RTU with her husband Norbert.

RTU signs purchase agreement with Merks Ltd. for reconstruction of FCE building (at 6A Kipsalas iela). Construction is scheduled to begin this fall and be completed by February 2021.

\section{August 24}

Celebrating the 30th anniversary of the Baltic Way, RTU men's choir «Gaudeamus» under the direction of Ivars Cinkuss participated in a largescale concert «Saule. Pērkons. Daugava» («Sun. Thunder. Daugava») in the Liktendārzā (the Garden of Destinies). One of the creators of the concert program was I. Cinkuss. The President of Latvia Egils Levits also attend the event.

\section{August 29}

Solemnly the new building of FMETA at 6B Kinpsalas iela was officially opened (the FCE was located at previously renovated building). Minister of Education and Science of the Republic of Latvia Ilga Šuplinska participatd in the opening ceremony. 
The Minister of Economics of the Republic of Latvia Ralfs Nemiro visited the RTU Campus.

\section{August 30}

The traditional meeting of RTU Rector with teaching staff and employees of RTU at the beginning of new study year.

President of Latvia Egils Levits congratulated RTU EHS on achievements at the Riga Castle, presenting Atis Kronvalds Foundation Award «Lielā Püce» («Big Owl») for the first place in the category of Small School Rating and the second place in the Star Rating created by the Foundation. 